\title{
The effect of kiwifruit (Actinidia deliciosa A Chev) and yellow flowered broom (Cytisus scoparius Link) pollen on the ovary development of worker honey bees (Apis mellifera $L$ )
}

\author{
SC Jay, DH Jay \\ Department of Entomology, University of Manitoba, Winnipeg, Manitoba R3T 2N2, Canada
}

(Received 21 December 1992; accepted 6 April 1993)

\begin{abstract}
Summary - The effect of feeding honey or honey-pollen mixtures (using pollen from yellow flowered broom, male kiwifruit flowers, female kiwifruit flowers) on the ovary development of worker honey bees was assessed after the bees had been caged without a queen for $14 \mathrm{~d}$. There was no significant difference in ovary development between bees fed honey and those fed pollen from female kiwifruit flowers mixed with honey, nor between bees fed broom pollen and pollen from male kiwifruit flowers when mixed with honey. Each of the latter 2 diets resulted in ovary development that was significantly greater than that of bees fed either honey only or pollen from female kiwifruit flowers mixed with honey. It is suggested that the nutritional value of various pollens for worker honey bees may be determined by examining their ovary development after being fed selected pollen diets in cages without a queen for $14 \mathrm{~d}$.
\end{abstract}

ovary development / pollen / nutritional value / Actinidia deliciosa

\section{INTRODUCTION}

Ovary development of worker honey bees is inhibited by the following: 1) mated adult queens (De Groot and Voogd, 1954; Butler, 1957; Velthuis, 1970a); 2) unsealed worker brood (Perepelova, 1929; Müssbichler, 1952; Milojevic and FilipovicMoskovljevic, 1959; Jay 1970, 1972; Kropácová and Haslbachová, 1971; Bai and Reddy, 1975); 3) sealed worker brood
(Milojevic and Filipovic-Moskovljevic, 1959; Jay, 1970; Bai and Reddy, 1975); 4) laying worker bees (Velthuis et al, 1965; Velthuis, 1970b; Jay and Nelson, 1973), and laying worker brood (Jay and Nelson, 1973). Alternatively, pollen that is rich in proteins, fats, minerals and vitamins promote, among other things, ovary development in newly emerged worker bees that are caged without queens (De Groot, 1952; Maurizio, 1954; Knox et al, 1971). 
While investigating the behaviour of honey bees on Chinese gooseberries (ie kiwifruit), Actinidia deliciosa (A Chev) in New Zealand, Jay and Jay (1984) observed that $96 \%$ of the bees carry pollen loads in their corbiculae; these loads usually consist of a mixture of pollen from flowers located on the male and female vines (note: kiwifruit is dioecious). Some bees, however, forage on either male or female flowers (Jay and Jay, 1984; Goodwin, 1987) at certain times and thus are of little value as kiwifruit pollinators. This selective foraging behaviour has been verified by examining pollen loads collected in pollen traps attached to honey bee colonies located in kiwifruit orchards (Jay and Jay, 1984; Clinch, 1986; Goodwin, 1987).

An attempt was made in this study to assess the relative nutritional value of pollen from male and female kiwifruit flowers for honey bees. This was done using a technique devised to measure ovary development of queenless worker bees in cages when exposed to various kinds of brood or comb (see Jay, 1968; Jay and Jay, 1976).

\section{MATERIALS AND METHODS}

Two trials each with 4 replicates were carried out using honey bees (Apis mellifera $\mathrm{L}$ ) of a yellow strain. Young worker bees were obtained by inserting combs of sealed brood, 1 from each of 10 colonies, into a box (with a screened bottom and solid wooden lid) that was placed on top of a well-populated colony of bees for $10 \mathrm{~h}$. This was undertaken at 2 different times using 2 different groups of 10 colonies each; these 2 groups provided the bees for the 2 trials. Plastic cages $(10 \times 7 \times 8 \mathrm{~cm})$ fitted with 2 feeders, 1 for water and 1 for honey or for a honey and freshly ground pollen mixture (1:10 vol) were used in the 2 trials.

When the trials began (see table I), 125 bees $<12 \mathrm{~h}$ old were placed in each cage. None of the cages contained a queen. Cages in treat- ment (a) contained feeders of honey; cages in treatment (b) contained feeders of a honeypoilen mixture (pollen from yellow flowered broom; Cytisus scoparius Link); cages in treatment (c) contained feeders of a honey-pollen mixture (poilen from male flowers of Actinidia deliciosa, cv Matua); cages in treatment (d) contained feeders of a honey-pollen mixture (pollen from female flowers of Actinidia deliciosa, cv Hayward). Honey and pollen mixtures were replaced daily. The trials were conducted in an incubator at $32 \pm 1{ }^{\circ} \mathrm{C}$ and at $50-60 \% \mathrm{RH}$ :

Pollen for the trials was collected in pollen traps attached to honey bee colonies, located in kiwifruit orchards and in areas where broom plants were growing and flowering in large numbers. Loads of male or female pollen from kiwifruit flowers were separated from the pollen trap collections using a low-power microscope. This was possible because female pollen loads are white while male pollen loads are off-white or creamy in colour (McKay, 1976; Jay and Jay, 1984). Broom pollen loads are deep orange in colour. Verification of pollen load composition was undertaken using high-power magnification coupled with reference slides and pollen keys. Broom pollen was used as a "control" in the trials as it is considered to be a valuable source of protein for rapid build-up of honey bee populations in New Zealand (Walsh, 1978).

Fourteen $d$ after the start of each trial, 25 bees were removed from each cage and dissected. Their ovaries were classified as 0 , undeveloped (score $=1$ ); I, slightly developed (swelling and (or) constriction of ovarioles (score $=2$ ); or II, well-developed ova usually present at various stages (score $=3$ ). The few ovaries that were between categories and difficult to classify were assigned alternatively to the next higher or the next lower category. Analysis of variance was used for statistical comparisons.

\section{RESULTS}

The results have been summarized in table 1 ; in both trials there was no significant difference in ovary development of worker bees that were fed honey and those that were fed honey mixed with pollen from female kiwifruit flowers, nor was there any 


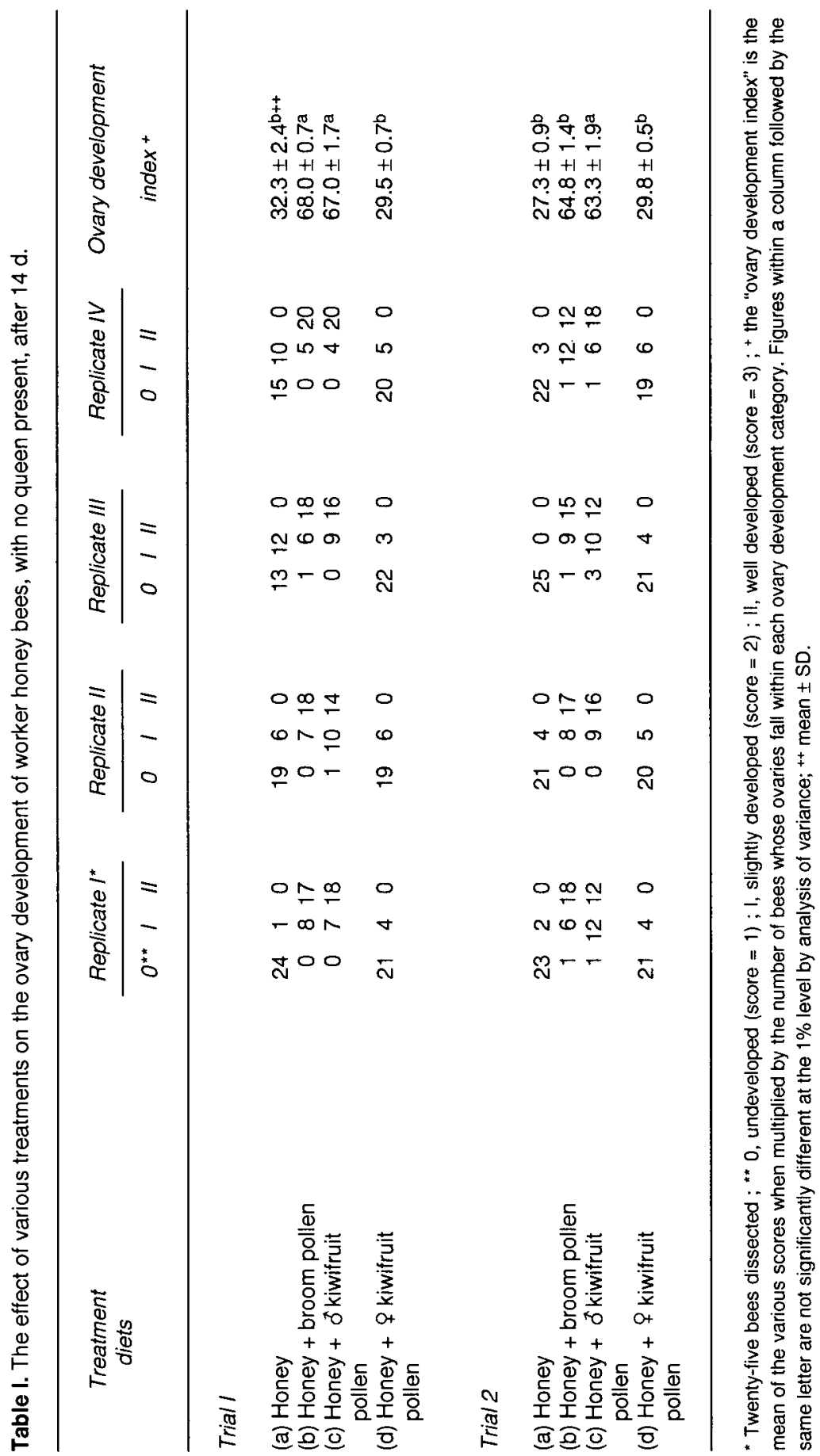


significant difference in ovary development of worker bees when fed honey mixed with broom pollen and honey mixed with pollen from male kiwifruit flowers. However, there was a significant difference $(P<0.01)$ in ovary development of worker bees when fed either honey or honey mixed with pollen from female flowers and honey mixed with broom pollen or honey mixed with pollen from male kiwifruit flowers.

Small amounts of comb were built around the feeders in most of the cages but at no time were eggs observed in the comb. Of interest was that the wax scales produced by bees fed on broom pollen were light yellow in colour while wax scales from bees fed on the other diets were colourless.

\section{DISCUSSION}

Female flowers of kiwifruit do not produce viable pollen, the pollen being "shrivelled" and lacking nucleii (McKay, 1976; Schmidt, 1978). Male kiwifruit flowers, in contrast, produce pollen in the binucleate stage (Rizet, 1945; Schmidt, 1978) which is $95-100 \%$ viable (McKay, 1976). Our results using worker ovary development indices indicate that pollen collected from broom and from male kiwifruit flowers has high nutritional value for honey bees; however this does not appear to be true for pollen from female kiwifruit flowers.

This bioassay may be useful in assessing the nutritional value of other pollens as well and if so would augment, or verify, data collected through chemical analyses of such pollens. The bioassay is relatively easy to use and requires little specialized equipment or dissection skills.

Although minor ovary development occurred in the bees of some replicates in which the bees were fed honey or pollen from female kiwifruit flowers this may have resulted from the bees using proteins from within their own bodies. The reason for the wax scales of the bees fed on broom being yellow in colour is not known.

Colonies of honey bees are often moved into kiwifruit orchards to assist in the pollination process. In general, bee populations decrease while the colonies are in these orchards despite being fed sugar syrup (this is done because kiwifruit flowers produce no nectar). It is also possible that the large amounts of pollen that are collected by the bees from female flowers (eg, Donavan, 1983; Jay and Jay, 1984; Goodwin, 1987) contribute to population declines in the colonies because, according to this study, the pollen appears to be of low nutritional value.

Thus, it is suggested that any contract that involves the pollination of kiwifruit using honey bees should take into consideration the colony population decreases that occur due to nectar and, or protein deficiencies.

\section{ACKNOWLEDGMENTS}

We thank $C$ Van Eaton, $R$ Berry and R Currie for their assistance with this research project.

Résumé - Influence du pollen de kiwi (Actinidia deliciosa A Chev) et du genêt à balai (Cytisus scoparius Link) sur le développement ovarien des ouvrières d'abeilles (Apis mellifera $L$ ). Les pollens, qui sont riches en protéines, lipides, minéraux et vitamines, favorisent, entre autres, le développement ovarien chez les ouvrières écloses en l'absence de reines. Dans cette étude la valeur nutritive relative du pollen de kiwi (fleurs mâles et femelles) vis-à-vis de l'abeille domestique a été étudiée à l'aide d'une technique qui mesure le 
développement ovarien d'ouvrières orphelines maintenues en cagettes. Les abeilles encagées, âgées de moins de $12 \mathrm{~h}$, étaient nourries avec a) soit du miel, soit un mélange de miel et de pollen. Le pollen provenait b) du genêt à balai (Cytisus scoparius, connu pour favoriser le développement rapide des populations d'abeilles), c) des fleurs mâles de kiwi (Actinidia deliciosa cv Matua), d) des fleurs femelles de kiwi (Actinidia deliciosa cv Hayward). Chaque cagette comportait en outre un abreuvoir. Les abeilles encagées ont été maintenues en étuve à $32 \pm 1^{\circ} \mathrm{C}$ et $50-60 \%$ HR durant $14 \mathrm{j}$, puis 25 abeilles ont été prélevées dans chaque cagette. Elles ont été disséquées et leurs ovaires classés en 3 catégories: non développés, peu développés et bien développés. On n'a pas trouvé de différences significatives entre le développement ovarien des ouvrières du régime a) et celles du régime d), ni entre celui des ouvrières du régime b) et celles du régime c). Mais il y avait une différence significative $(P<0,01)$ entre les ouvrières de ces 2 groupes (a,d et b,c). Nos résultats, basés sur l'indice de développement ovarien, montrent que le pollen de genêt à balai possède une valeur nutritive élevée et que ce n'est pas le cas pour le pollen de fleurs femelles de kiwi. Ce test biologique pourrait être utile pour déterminer la valeur nutritive d'autres pollens et augmenter ainsi, ou vérifier, les données obtenues sur ces pollens par analyse chimique. Le test est relativement facile et ne nécessite pas d'équipement spécialisé ni de compétences particulières pour la dissection.

développement ovarien / pollen / valeur nutritive / Actinidia deliciosa

Zussammenfassung - Der Einfluß des
Pollens der "Kiwifrucht (Actinidia deli-
ciosa A Chev) und des Gelben Ginsters
(Cytisus scoparius Link) auf die Ovar- entwicklung von Arbeiterinnen der Honigbiene (Apis mellifera L). Pollen, reich an Proteinen, Fett, Mineralen und Vitaminen, fördern unter anderem die Entwicklung der Ovarien von weisellosen, frisch geschlüpften Arbeitsbienen. In dieser Studie wurde der relative Futterwert des Pollens der männlichen und weiblichen Kiwifrucht-Blüte mit einer Technik untersucht, bei der die Ovarentwicklung weiselloser gekäfigter Arbeitsbienen gemessen wurde. Gekäfigte Arbeiterinnen, unter $12 \mathrm{~h}$ alt, wurden mit Honig oder einer HonigPollenmischung gefüttert. Der Pollen stammte vom Gelben Ginster, Cytisus scoparius, bekannt als wertvolle Pollenquelle zum raschen Aufbau der Bienenvölker, von männlichen Blüten von Actinidia deliciosa, Sorte Matua, und von weiblichen Blüten derselben Pflanze, Sorte Hayward. Zu dieser Diät kam in jeden Käfig noch ein Futtergefäß mit Wasser. Die gekäfigten Bienen wurden 14 Tage lang im Brutschrank bei einer Temperatur von $32 \pm$ $1^{\circ} \mathrm{C}$ und einer relativen Feuchtigkeit von $50-60 \%$ gehalten; anschließend wurden jedem Käfig 25 Bienen entnommen, präpariert und die Ovarien nach den Klassen unentwickelt, leicht entwickelt und gut entwickelt eingeteilt.

Es bestand kein signifikanter Unterschied in der Ovarentwicklung von Bienen, die mit Honig allein und von solchen, die mit einem Honiggemisch mit Pollen der weibliche Kiwifrucht gefüttert worden waren. Ebenso bestand kein signifikanter Unterschied in der Ovarentwicklung von Arbeiterinnen, die ein Gemisch mit Ginsterpollen oder denen, die Pollen von männlicher Kiwifrucht erhalten hatten. Es bestand jedoch ein signifikanter Unterschied $(P<$ $0.01)$ zwischen diesen beiden Gruppen, also zwischen Bienen nach Fütterung mit Honig allein oder mit einem Gemisch von weiblicher Kiwifrucht, und solchen, die entweder Ginsterpollen oder Pollen von männlicher Kiwifrucht erhalten hatten. 
Unsere Versuche, die auf Indizes der Ovarentwicklung von Arbeitsbienen aufbauen, bestätigen den hohen Nährwert des Ginsterpollens; dies scheint jedoch nicht für den Pollen der weiblichen Kiwifrucht zuzutreffen. Es wird vorgeschlagen, diesen Biotest zur Bestimmung des Nährwertes anderer Pollenarten zu verwenden; dadurch könnten die Daten aus chemischen Analysen dieses Pollens bestätigt oder vermehrt werden. Dieser Biotest ist relativ einfach anzuwenden, er verlangt kaum spezielle Einrichtungen oder besonderes Präparationsgeschick.

\section{Ovarentwicklung / Pollen Futterwert / Kiwifrucht}

\section{REFERENCES}

Bai ARK, Reddy CC (1975) Ovary development and egg laying in Apis cerana indica workers. J Apic Res 14 (3/4), 149-152

Butler DSG (1957) The control of ovary development in worker honeybees (Apis mellifera). Experientia 13, 256-257

Clinch P (1986) Sex of flowers important to pollinating bees. NZ Kiwifruit July 12

De Groot AP (1952) Amino-acid requirements for growth of the honey bee. Experientia 8, 192-194

De Groot AP, Voogd S (1954) On the ovary development in queenless worker bees (Apis mellifica L). Experientia 10, 384-385

Donavan B (1983) Kiwifruit pollination. In: Proc MAF Beekeepers' Seminar. Nelson NZ, July 18-24

Goodwin MG (1987) Ecology of honeybee (Apis mellifera $L$ ) pollination of kiwifruit (Actinidia deliciosa) (A Chev)). PhD thesis, Univ Auckland, NZ

Jay SC (1968) Factors influencing ovary development of worker honeybees under natural conditions. Can J Zool 46, 345-347

Jay SC (1970) The effect of various combinations of immature queen and worker honey- bees in colonies with and without queens. Can J Zool 48, 169-173

Jay SC (1972) Ovary development of worker honeybees when separated from worker brood by various methods. Can J Zool 50(5), $661-664$

Jay SC, Jay DH (1976) The effect of various types of brood comb on the ovary development of worker honeybees. Can J Zool 54 (10), 1724-1726

Jay DH, Jay SC (1984) Observations of honeybees on Chinese gooseberries ("kiwifruit") in New Zealand. Bee World 65(4), 155-166

Jay SC, Nelson EV (1973) The effects of laying worker honeybees (Apis mellifera $\mathrm{L}$ ) and their brood on the ovary development of other worker honeybees. Can J Zool 51, 629-632

Knox DA, Shimanuki $H$, Herbert EW (1971) Diet and longevity of adult honey bees. $J$ Econ Entomol 64(6), 1415-1416

Kropácová S, Haslbachová $H$ (1971) The influence of queenlessness and of unsealed brood on the development of ovaries in worker honeybees. J Apic Res 10(2), 57-61

Maurizio A (1954) Pollenernährung und Lebvensvorgänge bei der Honigbiene (Apis mellifica L). Landwirtsch Jahrb Schweiz 68, 115182

McKay SA (1976) Pollination and other factors affecting fruitset and size of kiwifruits. MSc thesis Univ California, Davis, USA

Milojevic BD, Filipovic-Moskovljevic V (1959) Gruppeneffekt bei Honigbienen. II Eierstockentwicklung bei Arbeitsbienen im Kleinvolk. Bull Acad Serb Sci Cl Sci Math Nat 25(7), 131-138

Müssbichler A (1952) Die Bedeutung äusserer Einflüsse und der Corpora allata bei der Afterweiselentstehung von Apis mellifica. $Z$ Vgl Physiol 34, 207-221

Perepelova LI (1929) Laying workers, the egglaying activity of the queen, and swarming. Bee World 10, 69-71

Rizet $\mathrm{G}$ (1945) Contribution à l'étude biologique et cytologique de "Actinidia chinensis. $C R$ Hebd Séances Mém Soc Biol 139, 140-142

Schmidt R (1978) Reproductive anatomy of Actinidia chinensis (Actinidiaceae). Bot Jahrb Syst Pflanzengesch Pflanzengeogr 100, 149195 (in German) 
Velthuis HHW (1970a) Queen substance from the abdomen of the honey bee queen. $Z \mathrm{Vgl}$ Physiol 70, 210-222

Velthuis HHW (1970b) Ovarian development in Apis mellifera worker bees. Entomol Exp App/ 13, 377-394
Velthuis HHW, Verheuen FJ, Gottenbos AJ (1965) Laying worker honeybee: similarities to the queen. Nature (Lond) 207(5003), 1314

Walsh RS (1978) Nectar and pollen sources of New Zealand. DF Jones Ltd, Wellington, NZ, $50 \mathrm{pp}$ 